\title{
Development of Interactive E-Module on Oxidation-Reduction Concept
}

\author{
Rabiatul Adawiyah ${ }^{1^{*}}$, Susilawati ${ }^{1}$ and Lenny Anwar $\mathbf{S}^{1}$ \\ 1 Postgraduate Program of Chemistry Education, Faculty of Teacher Training and Education, \\ Universitas Riau, Jl. Bina Widya KM. 12,5 Simpang Baru, Tampan, Pekanbaru, 28293, \\ Indonesia \\ *E-mail: rabiatuladawiyah995@gmail.com
}

Received: 03 October 2021; Accepted: 16 November 2021; Published: 31 December 2021

\begin{abstract}
This research aims to develop an interactive e-module on redox concept. Research and Development (R\&D) method was used in this study with a Plomp model. This model included three phases: preliminary, prototype or development, and assessment. Validation sheets and response questionnaires were used as research instruments. Six expert lecturers, consisting of three media and materials experts each, assessed the validity sheets. A small-scale test was carried out utilizing two approaches; a one-to-one test and a small group test. A one-to-one test was given to three students who had high, medium, and low abilities; while the small group test was conducted on three teachers and 30 students from three different schools, which are MAN 2 Pekanbaru, MAN 1 Pekanbaru, and SMA IT Al-fitiyah. The results showed that the interactive e-module was very valid and could be used in learning activities. This is indicated by the percentage of validation from material experts $89.27 \%$ and media experts $88.76 \%$. In a small-scale trial for a one-on-one test, the teacher's response $95.83 \%$ with very practical criteria; and student response test $87.73 \%$ with interesting criteria.
\end{abstract}

Keywords: flipbook, interactive e-module, redox reaction

DOI: https://doi.org/10.15575/jtk.v6i2.10288

\section{Introduction}

Curriculum changes all the time, especially in the field of education. This change is the result of globalization's development. According to the current $21^{\text {st }}$-century, skills represent the characteristics of students, including the ability to overcome obstacles and achieve success in education and the workplace (Ball et al., 2016). Preparing human resources with $21^{\text {st }}$-century abilities will be more effective if it is accomplished through education (Redhana, 2019). Education is a systematic process to improve human skills holistically, which allows affective, cognitive, and psychomotor potential to develop optimally (Syahroni et al., 2016). In the $21^{\text {st }}$-century, the implementation of ICT is quickly expanding in many aspects of life (Irwansyah et al., 2017), and education needs to take advantage of advances in science and technology to achieve its goals effectively and efficiently (Muhson, 2010).

Science and technology advancements appear to positively impact Indonesia, providing convenience, particularly in learning processes such as learning media (Istuningsih et al., 2018). Furthermore, the advancement of computers and the internet allows creates a limitless and flexible learning environment in the teaching and learning process, without regard to place and time, anytime and anywhere (Ganesan, 2009). Consequently, technological advancement must be leveraged, particularly in education. One method is to use ICT-based learning media, such as interactive media.

Interactive multimedia provides concepts and an exciting display that blends text, audio, video, images, and animation. Such a display will decrease students' boredom from 
monotonous learning, and the students will be more interested in grasping the material offered (Novitasari, 2016; Susanto et al., 2013). By implementing this interactive multimedia, an exciting and informative display of learning material can be obtained (Hasrul, 2010); therefore, an effective learning environment will be created (Nusir et al., 2013), and students will quickly grasp the material concepts (Wiana et al., 2018). Conceptual understanding is critical in learning since it allows the students to strengthen their skills in each class. Additionally, it can improve students' motivation to participate in learning activities. An e-module is an example of interactive media.

E-module is a digital learning media or nonprinted media created systematically for selfstudy purposes (Jaenudin et al., 2017). Emodule is an electronic version of a printed module consisting of learning materials, of which materials have essential roles in the learning processes (Parmin \& Peniati, 2012) in the printed version. Meanwhile, the e-module is technology-based teaching material that can be read in computer, and the establishments are designed using a software (Wahyuni et al., 2018; Nufus et al., 2020). When compared to printed modules, the advantages of e-modules are that teaching materials are packaged in interactive digital format, making it easier to navigate, allowing for the display/load of text, images, audio, video, and animation, and is equipped with formative tests/quizzes that allow immediate automatic feedback (Suarsana \& Mahayukti, 2013; Oktari et al., 2020; Munawarah et al., 2019). If it is reviewed from the benefits, e-module can make the learning process more exciting, interactive, and it can be done anytime and anywhere to improve the quality of learning (Perdana et al., 2017).

The development of e-module can be accomplished with the help of a program known as the kvisoft flipbook maker. Kvisoft flipbook maker is one of the applications or software to create an e-book, e-module, epaper, and e-magazine (Hidayatullah, 2016). This program is a medium for converting documents in PDF form into digital publications that seem like digital magazines and are diverse, innovative, and efficient (Fahmi et al., 2019). In contrast, the benefits of this application are not only in textual form but also in the ability to incorporate sound presentations, images, animations, videos, and movies so that the material presented is richer than conventional books and makes learning interactive and engaging rather than monotonous (Syamsurizal, 2015; Linda et al., 2018).

Chemistry is a science that investigates the theory, principles, and structure of a substance, changes in the composition or qualities of substances, and energy changes when a substance changes (Mai et al., 2018). Chemistry is a distinctive scientific discipline; its peculiarities are that it contains abstract concepts, but chemistry is very closely related to everyday life (Faizah et al., 2013). According to the findings of interviews with chemistry teachers at MAN 1 Pekanbaru, MAN 2 Pekanbaru, and SMA IT Al-Fityah, students struggle to grasp redox material concepts due to students who are still confused with those concepts. Furthermore, teachers continue to employ textbooks and Power Point; yet, textbooks and Power Point are viewed as less capable of explaining abstract chemical concepts. As a result, research into the development of interactive teaching material in an e-module is required to assist conceptual understanding and student motivation.

The developed interactive e-module in redox material will help teachers and students in the learning process. It can make easier to understand the concept of redox material and more motivated in learning since, in the emodule, there are explanations of redox concepts that are easy for students to understand, there are pictures, videos, animations, links, examples questions, and exercises that will make it easier for students to understand redox concepts. Several researchers have carried out the previous study on e-module, one of them is Wijayanto \& Zuhri (2014), who elucidates their research results that e-module is one of the valuable teaching materials to achieve the learning purposes. It can develop mathematical 
problem-solving skills, and it is by the characteristics of curriculum 2013. Hereafter, Nufus et al. (2020) assert in their study that the use of teaching material in the form of an emodule created using Kvisoft Flipbook Maker application is valid to be used as teaching material to improve students' understanding of stoichiometric.

Based on the enlightenment above, the study was conducted to develop an interactive emodule using the Kvisoft Flipbook Maker application for chemistry learning of redox material.

\section{Research Method}

This research used research and development (R\&D) method based on the plomp model, which included the following phases: 1) preliminary research phase, which included field study analysis, curriculum analysis, and student analysis; 2) development or prototype phase, which included mapping of learning material, designing of e-module display (storyboard), and constructing the e-module product; and 3) assessment phase, which included validation and small-scale trial and large-scale trial (Plomp, 2013). However, this study was limited to a small-scale trial.

The development stage of an interactive emodule in redox material was carried out at Postgraduate of Chemistry Education, Faculty of Teacher Training and Education, University of Riau, and for one to one test was conducted at MAN 1 Pekanbaru with three students, and a small-scale trial was conducted at MAN 2 Pekanbaru, MAN 1 Pekanbaru, and SMA IT AlFityah with three chemistry teachers and 30 students.

The data analysis technique used validation sheets teacher and student response questionnaires. The assessment of media validation sheets was carried out by six expert lecturers, comprising of three media experts and three material experts. The data analysis technique of the validity and attractiveness of the interactive redox e-module uses a Likert scale with a rating of 1 (strongly disagree), 2 (disagree), 3 (agree), and 4 (strongly agree) (Sugiyono, 2017). From the Likert scale rating category table, the average percentage of each component would be calculated. Giving meaning and making decisions about the quality of e-module products used validity criteria according to Riduwan (2012), percentage size <20 (very invalid), 21-40 (invalid), 41-60 (quite valid), 61-80 (valid), 81100 (very valid).

The questionnaire analysis of the responses of high school chemistry teachers and students was used to determine e-module response data. The percentage for teacher responses are 0\%-20\% (very impractical), 21\%-40 \% (Less Practical), 41\%-60\% (Quite Practical), 61\%$80 \%$ (Practical), $81 \%-100 \%$ (Very Practical) (Pradilasari et al., 2019). The attractiveness criterion for student responses are $<49 \%$ (Not attractive), 50\%-59\% (Unattractive), 60\%-79\% (Quite Attractive), and 80\%-100\% (Attractive) (Akbar \& Sriwijaya, H., 2011).

\section{Result and Discussions}

The researchers' development results are to generate an interactive e-module for redox that can be used as interactive teaching material. This study was conducted using research and development (R\&D) design using the Plomp model (Plomp, 2013).

\subsection{Preliminary Phase}

The first phase is preliminary. An initial investigation comprises field study analysis, curriculum analysis, material analysis, and student analysis.

\subsubsection{Field Study Analysis}

The field study analysis interviewed three chemistry teachers from three different schools: MAN 1 Pekanbaru, MAN 2 Pekanbaru, and SMA IT Al-fitiyah. The interviews revealed that students' understanding of redox material concepts was still insufficient, as they struggled to understand redox concepts, to determine the oxidation number of an element in a compound or ion, redox reactions, and to determine compound nomenclature according to IUPAC, the 
teaching materials used by teachers during the learning process were textbooks, worksheets, and PowerPoint. However, they had never used e-modules in the learning process, and the student's enthusiasm to learn was still low. These interview results were in line with a study conducted by Andrianie et al. (2018), Sulalaha et al. (2017), and Suryani et al. (2014), which revealed that redox material was classified as a complex subject for students.

\subsubsection{Curriculum Analysis}

Curriculum analysis was performed to assess the curriculum utilized by the schools to ensure that the preparation and development of e-modules were following the curriculum used. 2017 revision of curriculum 2013 is used in this study. Analysis of the redox material curriculum based on the essential competencies of 3.9 and 4.9. The following indicators were obtained as a consequence of this analysis: 1) Explaining the difference of reduction and oxidation concepts, 2) Analyzing the oxidation number of the element atoms in a compound or ion, 3) Analyzing reaction in a redox reaction, 4) Identifying the compound name according to IUPAC.

\subsubsection{Material Analysis}

The material analysis developed in this emodule is redox material; thus, the concept mapping of redox material is obtained in Figure 1.

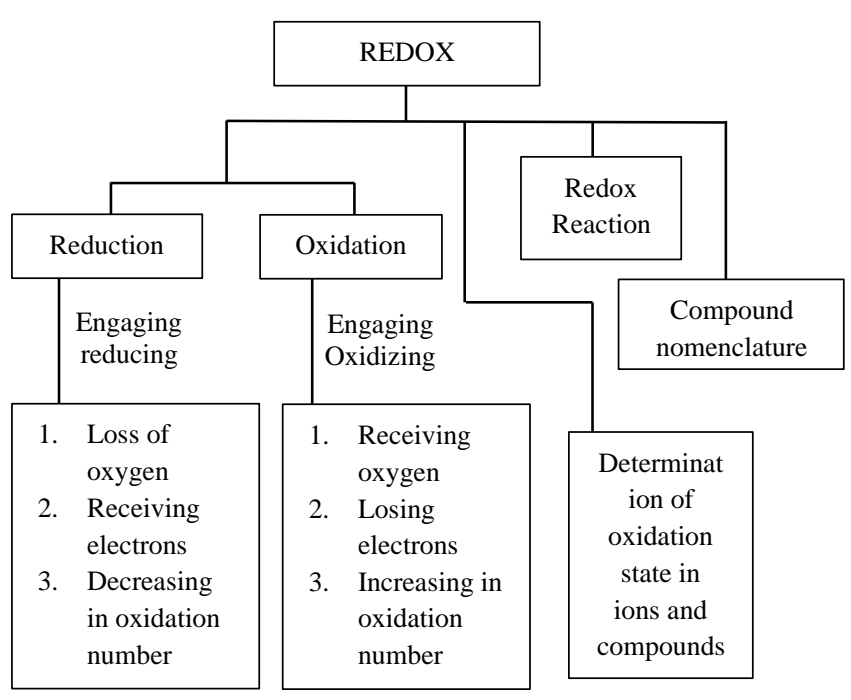

Figure 1. Redox Mind Map

\subsubsection{Students Analysis}

Before starting the study, a student analysis was carried out by distributing questionnaires to determine the condition of the students' learning processes. The subjects of this study were 30 high school students in their $10^{\text {th }}$ grade. According to the questionnaires distributed to the students, $80 \%$ of students considered redox material difficult to understand, and $90 \%$ of students were not motivated in the learning process since it was only using textbooks, and the students had never used it e-modules in the learning process. This is why the requirement for emodules can help students understand the concept of redox material and motivate them to learn.

\subsection{Development Phase}

The second phase is the development or prototype. This is one of the most important stages of Plomp because it compiles the first design of the product design to be developed. The stages included in the prototype stage are described below.

\subsubsection{Mapping of Learning Material}

Mapping learning material is one of the stages teachers need to scheme and develop a Lesson Plan. Mapping aims to develop emodule in a structured and directed manner in the development and by the learning objectives of the redox material.

\subsubsection{E-module Display Design (Storyboard)}

The establishment of this storyboard aims to simplify the researchers in developing the emodule product. The order of storyboard design is arranged based on the Direktorat Pembinaan Sekolah Menengah Atas (2017): 1) E-module cover page design, including the title of the e-module, the name of the class subject, and the semester of the image that describes the title of the e-module or the name of the subject, the identity of the author; 2) E-module identity design, comprising of preface, drafting team, table of contents, description, instructions for using e-modules; 3) Preliminary design of e-modules, namely: core competencies and basic competencies, mind maps; 4) Design of e-module contents, 
namely: learning objectives, material descriptions, series of materials, summaries, self-tests (tasks), exercises, evaluations, feedback (self-assessment); 5) E-module cover design, namely: answer key, glossary, bibliography; and 6) E-module cover page design, namely: author's identity.

\subsubsection{Product Construction}

The first stage of e-module construction is compiling the contents of redox material using a previously created e-module design. Emodule content is compiled using Microsoft Publisher, with the design based on the storyboard. When the e-module material's content is finished, save the file in PDF format. The final stage of product construction is carried out using the kvisoft flipbook maker application once the materials and supporting files are complete and under the needs. The produced e-module files are integrated with the required content in the kvisoft flipbook maker application. When completed, the emodule is published in HTML format.

\subsection{Assessment Phase}

\subsubsection{Validation}

The validation of the developed redox interactive e-module is carried out by 6 experts, 3 of them are material experts and the rest are media experts. After obtaining several suggestions from the validators, the e-module will be revised later. The following figures demonstrate several displays of an e-module after it has been revised.

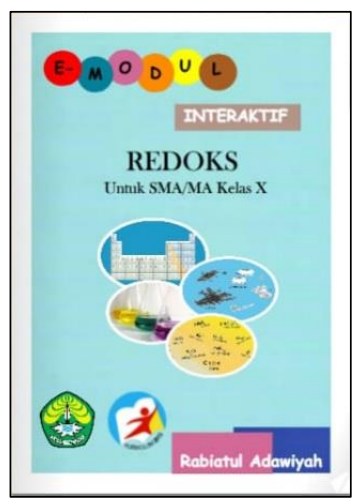

Figure 2. E-module Cover

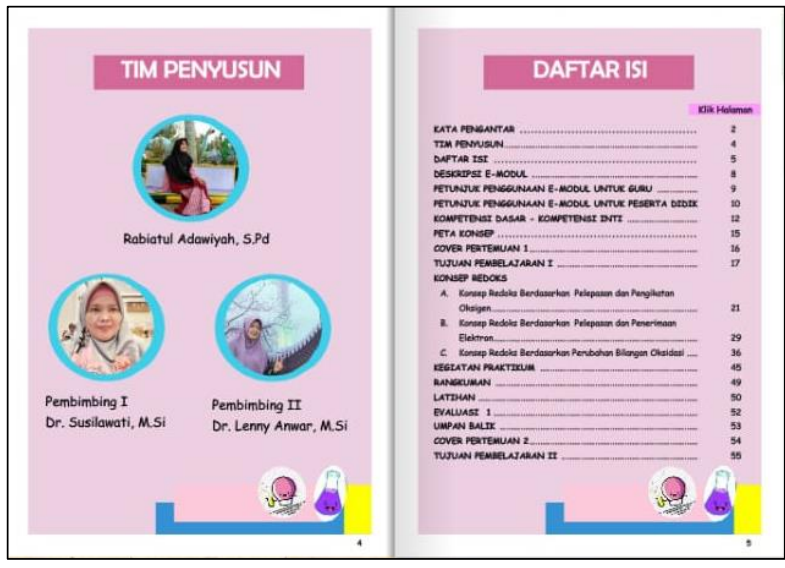

Figure 3. Media Creation Team and E-Module Table of Contents

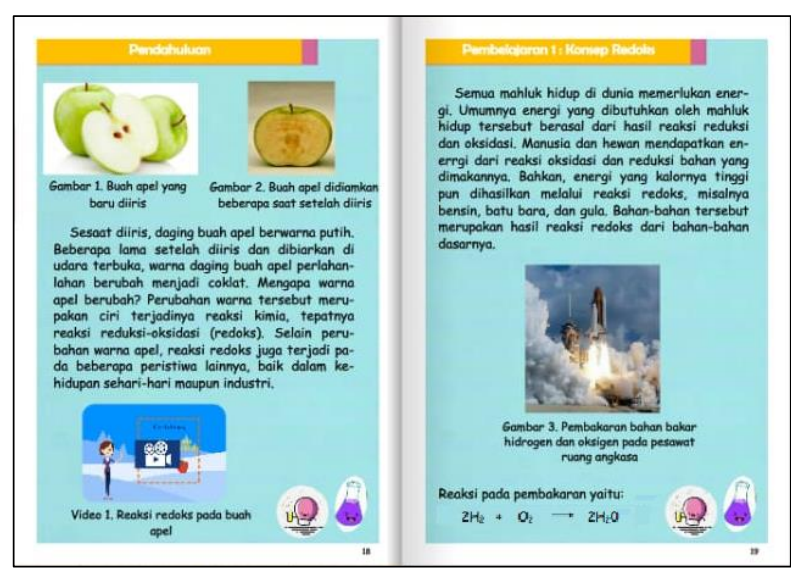

Figure 4. E-module Material

The material experts' validation assessment includes content feasibility, pedagogy, language assessment, and graphics can be seen in Figure 5. According to the material experts' validator assessment, the developed redox interactive e-module met material validity criteria with an average percentage of $89.27 \%$ and was classified as very valid. These validation findings are the outcome of an emodule revision based on suggestions and comments from the validators team. This is in line with the results of a study conducted by Septryanesti \& Lazulva (2019), Julia \& Utami (2020) and Larasati et al. (2018) where the results of the media expert validation are very valid. 


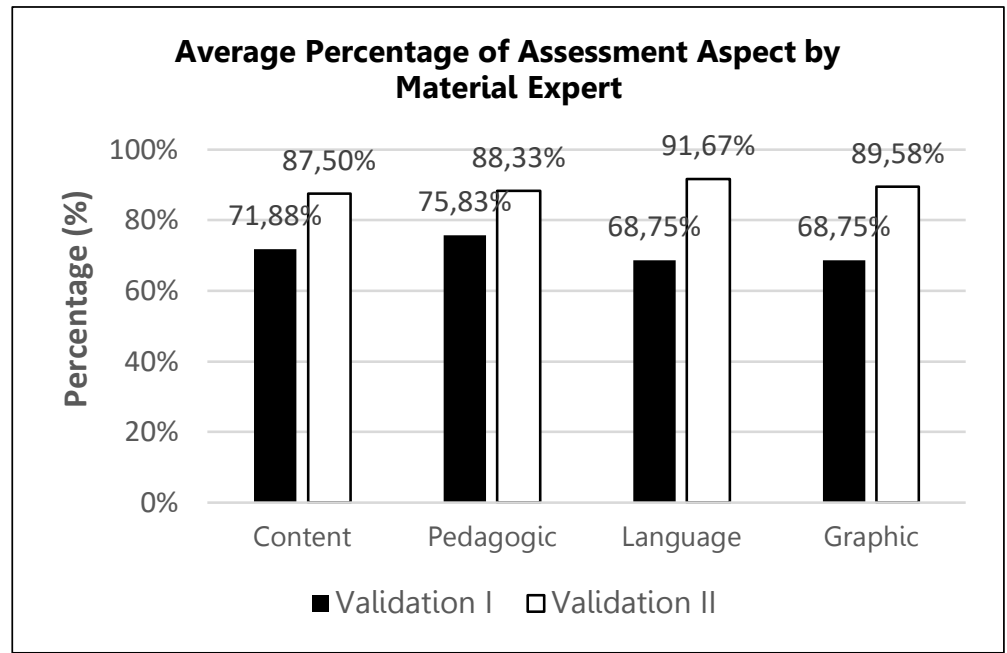

Figure 5. Redox Interactive E-module Validation Results by Material Expert

Media experts conduct the validation above out. The evaluation includes e-module size, cover design, and content design. Figure 6 depicts the validation results of media experts to the prototype.

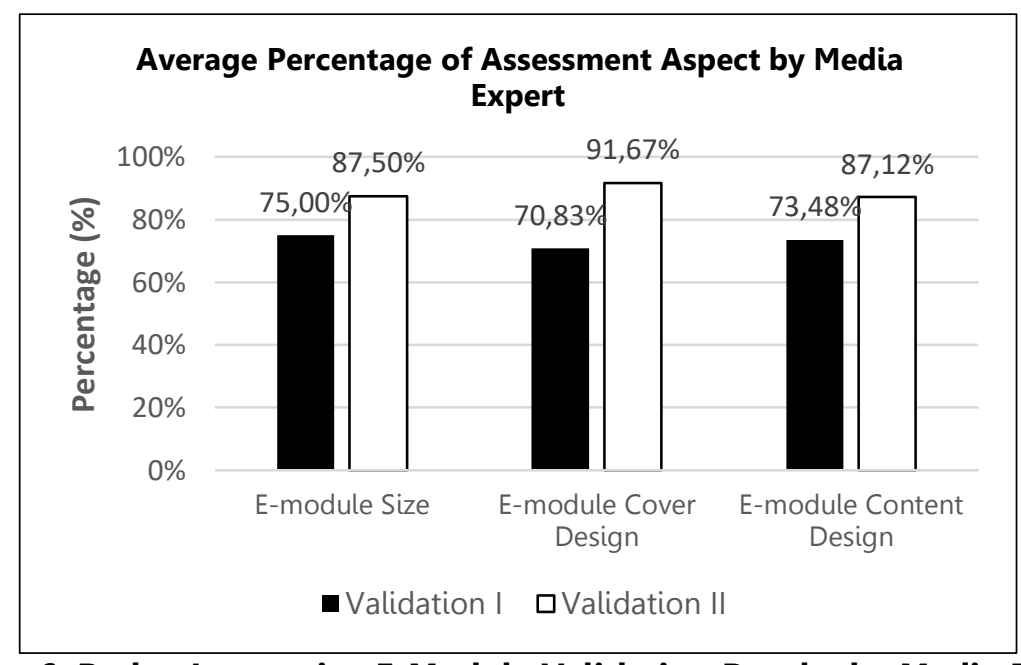

Figure 6. Redox Interactive E-Module Validation Results by Media Expert

According to validator assessment by the media experts, it was obtained that the developed redox interactive e-module had met media validity criteria with a percentage of $88.76 \%$ in a very valid criterion. This validation result is obtained since the emodule has been revised by the suggestions and comments from the validator team. This validation result is in line with a study conducted by Septryanesti \& Lazulva (2019), Julia \& Utami (2020), Imansari \& Sunaryantiningsih (2017) which states that the validation result of media experts is very valid.

\subsubsection{Small Scale Trial}

The interactive redox e-module has been validated by material experts and media experts and is declared valid; the redox interactive e-module is then evaluated using a small-scale trial utilizing a questionnaire to determine teacher and student responses. The small-scale trial employs two methods: oneto-one test and small group test. One to one test was carried out to three students who had high, medium, and low abilities, and the small group test was carried out to three teachers and 30 students of three different schools, namely MAN 2 Pekanbaru, MAN 1 Pekanbaru, and SMA IT Al-fitiyah. The one to one test that Jurnal Tadris Kimiya 6, 2 (December 2021): 202-212

This is an open access article under CC-BY-SA license (https://creativecommons.org/licenses/by-sa/4.0/) 
was conducted to 3 students obtained positive and negative comments toward the interactive e-module in redox material, it could be seen in Table 1, and the results of one to one test and small group test that comprised the teachers and students responses to the redox interactive e-module could be seen in Table 2 .

Table 1. One to One Test Positive and Negative Comments on The Interactive Emodule Redox Material

\begin{tabular}{ll} 
Positive Comment & \multicolumn{1}{c}{$\begin{array}{c}\text { Negative } \\
\text { Comment }\end{array}$} \\
\hline 1. & $\begin{array}{l}\text { Redox material } \\
\text { interactive e-module is }\end{array}$ \\
very easy to understand & writing typo \\
2. The colors image and \\
video used in the e- \\
module redox material \\
are very interesting that \\
it makes them more \\
excited to learn
\end{tabular}

According to comments of the e-module users in Table 1, it is known that the use of e-module in the learning processes makes students more interested in learning compared to the use of textbooks since the e-module is equipped with pictures, videos that are easier for students to understand. Comments given by the students indicate that using kvisoft flipbook maker application in creating the emodule as software can create an interactive teaching material; hence, it is easier for users to learn the subject matter. It is in line with Munir's theory (2008) which states that interactive multimedia has privileges such as being interactive by providing easy feedback, freedom to determine learning topics, and systematic control in the learning process.

Table 2. Small Group Test Results (Teachers and Students) on Redox Interactive EModules

\begin{tabular}{|c|c|c|}
\hline Small scale test & $\begin{array}{c}\text { Average } \\
\text { percentage } \\
(\%)\end{array}$ & $\begin{array}{l}\text { Attractive- } \\
\text { ness } \\
\text { Criteria }\end{array}$ \\
\hline $\begin{array}{l}\text { Small group testing } \\
\text { (teachers) }\end{array}$ & 95.83 & $\begin{array}{c}\text { Very } \\
\text { Practical }\end{array}$ \\
\hline $\begin{array}{l}\text { Small group testing } \\
\text { (students) }\end{array}$ & 87.73 & Interesting \\
\hline
\end{tabular}

The teacher response results obtained are efficient, as shown in Table 2. During the small group test, the teachers administer support to the development of the e-module, since they think that the e-module is under current development; it is challenging to ask students to read books because everything is already on the gadget. Therefore, students are expected to be interested in reading and repeating lessons using e-modules in the learning process. In addition, according to the teachers, the kvisfot flipbook maker-based emodule that the researcher developed on redox material is very practical and easy to use.

Interesting criteria obtained in the results of the student response questionnaire are based on the responses given by students through a questionnaire. They consider that e-module using kvisoft flipbook maker has an attractive appearance. The presentation makes students more enthusiastic about learning redox material. The color composition in the emodule is fascinating; there is information, pictures, videos that make it easier to understand the material; additionally, the use of e-modules makes learning activities more fun. This e-module can be studied by students anywhere and anytime according to the student needs. This is in line with the theory that the use of e-modules can be studied anywhere and anytime, not limited to learning hours at school (Dewi \& Lestari, 2020).

\section{Conclusions}

The generated interactive e-module product is categorized in extremely valid criteria and is interesting to be employed in $10^{\text {th }}$-grade students of High Schools, particularly for redox material. According to the validation percentages scores of material and media experts, this e-module receives $89.27 \%$ from material experts and $88.76 \%$ from media experts, indicating that it meets a very valid criterion. Meanwhile, on a small scale, namely the small group test, the teacher and student responses are obtained on average consecutively, namely $95.83 \%$ in very practical criteria and $87.73 \%$ in interesting criteria, indicating that this e-module can be used as

\footnotetext{
This is an open access article under CC-BY-SA license (https://creativecommons.org/licenses/by-sa/4.0/)
} 
teaching material in redox material learning for $10^{\text {th }}$-grade students of High Schools.

\section{References}

Akbar, S. \& Sriwijaya, H. (2011). Pengembangan kurikulum dan pembelajaran ilmu pengetahuan sosial. Malang: Cipta Media.

Andrianie, D., Sudarmin, \& Wardani, S. (2018). Representasi kimia untuk mereduksi miskonsepsi siswa pada materi redoks melalui penerapan model pembelajaran inkuiri terbimbing berbantuan LKS. Chemistry in Education, 7(2), 69-76. Retrieved from https://journal.unnes.ac.id/sju/index.p hp/chemined/article/view/17672

Ball, A., Joyce, H. D., \& Butcher, D. A. (2016). Exploring $21^{\text {st }}$ century skills and learning environments for middle school youth. International Journal of School Social Work, 1(1), 1-15. Retrieved from https://newprairiepress.org/ijssw/vol1 /iss1/1/

Dewi, M. S. A., \& Lestari, N. A. P. (2020). Emodul interaktif berbasis proyek terhadap hasil belajar siswa. Jurnal Imiah Pendidikan dan Pembelajaran, 4(3), 433-441. http://dx.doi.org/10.23887/jipp.v4i3.2 8035

Direktorat Pembinaan Sekolah Menengah Atas. (2017). Panduan praktis penyusunan e-modul. Jakarta: Kementerian Pendidikan dan Kebudayaan.

Fahmi, S., Priwantoro, S. W., Cahdriyana, R. A., Hendroanto, A., Rohmah, S. N., \& Nisa, L. C. (2019). Interactive learning media using kvisoft flipbook maker for mathematics learning. In Journal of Physics: Conference Series, 1188(1), 1$6 . \quad$ https://doi.org/10.1088/17426596/1188/1/012075
Faizah, Miswadi, S. S., \& Haryani, S. (2013). Pengembangan perangkat pembelajaran berbasis masalah untuk meningkatkan soft skill dan pemahaman konsep. Jurnal Pendidikan IPA Indonesia, 2(2), 120-128. https://doi.org/10.15294/jpii.v2i2.2712

Ganesan, N. (2009). Rapid development of multimedia instructional modules for information technology education. Journal of International Technology and Information Management, 18(1), 83-97. Retrieved from https://scholarworks.lib.csusb.edu/jiti m/vol18/iss1/5/

Hasrul, B. (2010). Langkah-langkah pengembangan pembelajaran multimedia interaktif (the developing steps of interactive multimedia learning). MEDTEK Journal, 2(1), 1-7. Retrieved from http://ftunm.net/\%20medtek/JurnalMedtekVol .2No.1April_2010/hasrulbakri.pdf

Hidayatullah, M. S. (2016). Pengembangan media pembelajaran berbasis flip book maker pada mata pelajaran elektronika dasar di SMK Negeri 1 Sampang. Jurnal Pendidikan Teknik Elektro, 5(1), 83-88. Retrieved from https://ejournal.unesa.ac.id/index.php /jurnal-pendidikan-teknikelektro/article/view/13674

Imansari, N. \& Sunaryantiningsih, I. (2017). Pengaruh penggunaan e-modul interaktif terhadap hasil belajar mahasiswa pada materi kesehatan dan keselamatan kerja. Jurnal Ilmiah Pendidikan Teknik Elektro, 2(1), 11-16. http://dx.doi.org/10.30870/volt.v2i1.14 78

Irwansyah, F. S., Lubab, I., Farida, I., \& Ramdhani, M. A. (2017). Interactive electronic module in chemistry lessons. Journal of Physics: International Conference on Mathematics and Science Education (ICMSCE), 895, 1-7. 
https://doi.org/10.1088/1742-

6596/895/1/012009

Istuningsih, W., Baedhowi, B., \& Sangka, K. B. (2018). The effectiveness of scientific approach using e-module based on learning cycle 7E to improve students' learning outcome. International Journal of Educational Research Review. 3(3), 75-85. https://doi.org/10.24331/ijere.449313

Jaenudin, A., Baedhowi, \& Murwaningsih T. (2017). The effectiveness of the emodule of economics learning on problem-based learning used to improve students' learning outcomes. International Conference on Teacher Training and Education, 158, 30-36. https://doi.org/10.2991/ictte-

17.2017.32

Julia, I. \& Utami L. (2020). Desain dan uji coba e-modul kimia berbasis problem solving pada materi larutan penyangga untuk kelas XI SMA semester II. Journal of Research and Education Chemistry, 2(1), 1-11. https://doi.org/10.25299/jrec.2020.vol 2(1).4862

Larasati, M., Fibonacci, A., \& Wibowo, T. (2018). Pengembangan modul berbasis problem based learning pada materi polimer kelas XII SMK Ma'arif NU 1 sumpiuh. Jurnal Tadris Kimiya, 3(1), 207-216. https://doi.org/10.15575/jtk.v3i1.2038

Linda, R., Sulistya, H. I., \& Putra, T. P. (2018). Interactive e-module development through chemistry magazine on kvisoft flipbook maker application for chemistry learning in second semester at second grade senior high school, Journal of Science Learning, 2(1), 2125.

https://doi.org/10.17509/jsl.v2i1.1293 3

Mai, L. Y., \& Utiya. (2018). Development of student worksheet science literacy in XI grade on chemical equilibrium topic. Unesa Journal of Chemistry Education, 7(3), 308-314. https://doi.org/10.26740/ujced.v7n3.p $\% 25 p$

Muhson, A. (2010). Pengembangan media pembelajaran berbasis teknologi informasi. Jurnal Pendidikan Akuntansi Indonesia, 8(2), 1 - 10. https://doi.org/10.21831/jpai.v8i2.949

Munawarah, S., Seruni, R., Nurjayadi, M., \& Kurniadewi, F. (2019). Pengembangan e-module biokimia pada materi metabolisme karbohidrat untuk mahasiswa program studi kimia. Jurnal Tadris Kimiya, 4(1), 69-77. https://doi.org/10.15575/jtk.v4i1.4679

Munir. (2008). Multimedia: konsep dan aplikasi pendidikan. Bandung: Alfabeta.

Novitasari, D. (2016). Pengaruh penggunaan multimedia interaktif terhadap kemampuan pemahaman konsep matematis siswa. Jurnal Pendidikan Matematika \& Matematika, 2(2), 8-18. https://doi.org/10.24853/fbc.2.2.8-18

Nufus, H., Susilawati, \& Linda R. (2020). Implementation of e-module stoiciometry based on kvisoft flipbook maker for increasing understanding study learning concepts of class $\mathrm{X}$ senior high school. Journal of Educational Sciences, 4(2), 261-272. http://dx.doi.org/10.31258/jes.4.2.p.26 $1-272$

Nusir, S., Alsmasi, I., Al-Kabi, M., \& Sharadgah F. (2013). Studying the impact of using multimedia interactive programs on children's ability to learn basic math skills. Journal E-Learning and Digital Media, 10(3), 305-319. https://doi.org/10.2304/elea.2013.10.3 .305

Oktari, B., Susilawati, \& Copriady J. (2020). Implementation of oriented literated science e-module to improve critical

Jurnal Tadris Kimiya 6, 2 (December 2021): 202-212

This is an open access article under CC-BY-SA license (https://creativecommons.org/licenses/by-sa/4.0/) 
skills thinking about in hydrocarbon material. Journal of Educational Sciences, 4(2), 347-356. https://doi.org/10.31258/jes.4.2.p.347356

Parmin \& Peniati, E. (2012). Pengembangan modul mata kuliah strategi belajar mengajar IPA berbasis hasil penelitian pembelajaran. Jurnal Pendidikan IPA Indonesia, 1(1), 8-15. https://doi.org/10.15294/jpii.v1i1.2006

Perdana, F. A., Sarwanto, Sukarmin, \& Sujadi, I. (2017). Development of e-module combining science process skills and dynamics motion material to increasing critical thinking skills and improve student learning motivation senior high school. International Journal of Science and Applied Science: Conference Series, 1(1), 45-54. Retrieved from https://core.ac.uk/download/pdf/2054 56363.pdf

Plomp, T. (2013). Educational design research: an introduction. Educational design research, 11-50. Retrieved from https://ris.utwente.nl/ws/portalfiles/po rtal/14472302/Introduction_20to_20e ducation_20design_20research.pdf

Pradilasari, L., Gani, A. \& Khaldun, I. (2019). Pengembangan media pembelajaran berbasis audio visual pada materi koloid untuk meningkatkan motivasi dan hasil belajar siswa. Jurnal Pendidikan Sains Indonesia, 7(1), 9-15. https://doi.org/10.24815/jpsi.v7i1.132 93

Redhana, I W. (2019). Mengembangkan keterampilan abad ke-21 dalam pembelajaran kimia. Jurnal Inovasi Pendidikan Kimia, 13(1), 2239-2253. https://doi.org/10.15294/jipk.v13i1.17 824

Riduwan. (2012). Skala pengukuran variabelvariabel penelitian. Bandung: Alfabeta.
Septryanesti, N., \& Lazulva. (2019). Desain dan uji coba e-modul pembelajaran kimia berbasis blog pada materi hidrokarbon. Jurnal Tadris Kimiya, 4(2), 202-215. https://doi.org/10.15575/jtk.v4i2.5659

Suarsana \& Mahayuti, G. A. (2013). Pengembangan e-modul berorientasi pemecahan masalah untuk meningkatkan keterampilan berpikir kritis mahasiswa. Jurnal Pendidikan Indonesia, 2(2), 264-275. http://dx.doi.org/10.23887/jpiundiksha.v2i2.2171

Sugiyono. (2017). Memahami penelitian kualitatif. Bandung: Alfabeta.

Sulalaha, W. A., Suryadharma, I. B., \& Sukarianingsih, D. (2017). Analisis kesulitan peserta remidi dalam memahami konsep reaksi redoks. Jurnal Pembelajaran Kimia, 2(1), 14-20. http://dx.doi.org/10.17977/um026v2i1 2017p014

Suryani, D. I., Suhery, T., \& Ibrahim, A. R. (2014). Pengembangan modul kimia reaksi reduksi oksidasi kelas X SMA. Jurnal Pendidikan Kimia, 1(1), 18-28. https://doi.org/10.36706/jppk.v1i1.238 0

Susanto, Dewi, N. R., \& Irsadi, A. (2013). Pengembangan multimedia interaktif dengan education game pada pembelajaran IPA terpadu tema cahaya untuk siswa SMP/MTs. Science Education Journal, 230-238. https://doi.org/10.15294/USEJ.V2I1.18 29

Syahroni, M. W., Dewi, N. R., \& Kasmui. (2016). The effect of using digimon (science digital module) with scientific approach at the visualization of students' independence and learning results. Journal Pendidikan IPA Indonesia, 5(1), 116-122. https://doi.org/10.15294/jpii.v5i1.5800 
Syamsurizal, Haryanto, \& Chairani, N. (2015).

Pengembangan e-modul berbasis keterampilan proses sains pada materi kesetimbangan kimia untuk tingkat SMA, Prosiding SEMIRATA 2015 bidang MIPA BKS-PTN Barat, 655-661, Pontianak: Universitas Tanjungpura. Retrieved from https://jurnal.untan.ac.id/index.php/se mirata2015/article/view/14286/12776

Wahyuni, S. I., Noer, A. M., \& Linda, R. (2018). Development of electronic module using kvisoft flipbook maker application on the chemical equilibirium. Proceeding of the 2nd URICES, 178-189, Pekanbaru: Universitas Riau. Retrieved from https://ices.prosiding.unri.ac.id/index. php/ICES/article/view/6417

Wiana, W., Barliana, M. S., \& Riyanto, A. A. (2018). The effectiveness of using interactive multimedia based on motion graphic in concept mastering enhancement and fashion designing skill in digital format. ljet, 13(2), 4-20. https://doi.org/10.3991/ijet.v13i02.783 0

Wijayanto, \& Zuhri, M. S. (2014). Pengembangan e-modul berbasis flip book maker dengan model project based learning untuk mengembangkan kemampuan pemecahan masalah matematika. Prosiding Mathematics and Sciences Forum 2014, 625-628, Semarang: Seminar Universitas PGRI. Retrieved from

http://prosiding.upgris.ac.id/index.php /masif2014/masif2014/paper/view/48 7 